
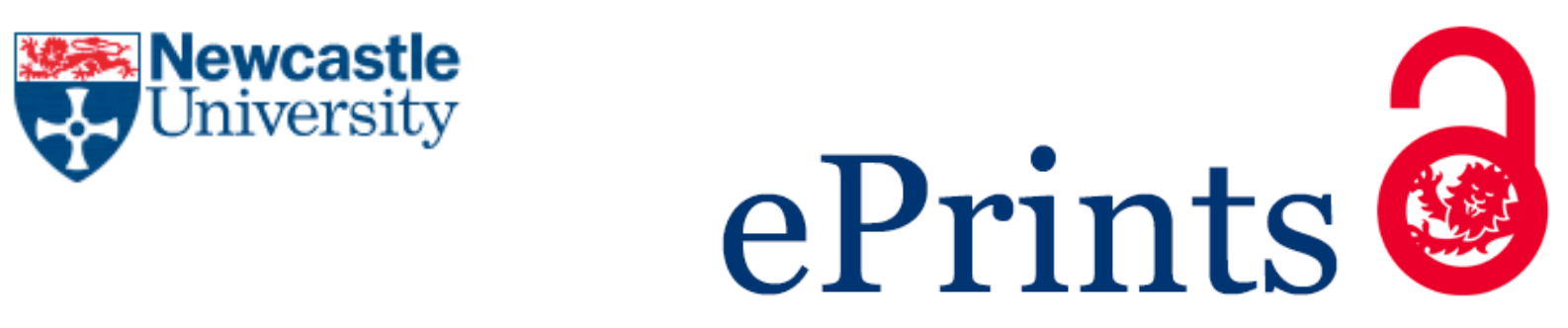

Pásztor A. (2014)

Divergent pathways: the road to higher education for second-generation

Turks in Austria.

Race Ethnicity and Education

DOI: 10.1080/13613324.2014.911164

\title{
Copyright:
}

This is an Accepted Manuscript of an article published by Taylor \& Francis in Race Ethnicity and Education on 15/05/2014, available online: http://dx.doi.org/10.1080/13613324.2014.911164

Date deposited:

$02 / 10 / 2014$

Embargo release date:

15 November 2015

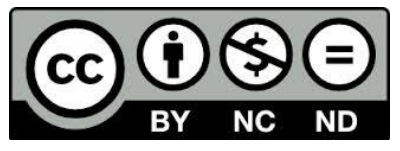

This work is licensed under a

Creative Commons Attribution-NonCommercial-NoDerivatives 4.0 International licence 


\section{Divergent Pathways: The Road to Higher Education for Second- Generation Turks in Austria}

Adél Pásztor ${ }^{1}$

School of Geography, Politics and Sociology, Newcastle University, Newcastle upon Tyne, UK

Abstract

The paper aims to explore immigrant educational pathways in relation to access to higher education in the Austrian context. Specifically focusing on Turkish youth, the author presents case studies of students who successfully entered higher education in spite of their disadvantaged social, ethnic and geographic background. By further enhancing Ball's distinction (Ball, Reay, and David 2002) between embedded and contingent choosers, the paper provides an in-depth understanding of the cultural and structural context in which these students' educational choices are played out. Finally, reaching out for Turner's (1960) notion of sponsored mobility, the paper reflects on how the process of early selection reduces the opportunities for immigrant youth to access seemingly open and free higher education.

Key words: Austria; ethnic minority students; higher education choice; second generation Turks; tracking

\footnotetext{
${ }^{1}$ Email: adel.pasztor@ncl.ac.uk
} 


\section{Introduction}

In spite of the rapid expansion of higher education in the $21^{\text {st }}$ century, access is still restricted in many developed countries. While many European countries assume central responsibility for meeting the aspirations of their citizens, different countries use different mechanisms to allocate the available places among the "qualifying" students. There are countries known for their high tuition fees (such as the US and the UK) which tend to select those worthy of access almost at the doors of higher education institutions, whilst others (e.g. Austria, Germany, the Netherlands) allocate government funded higher education places by relying on the track system to pre-select those allowed to progress early on. In the following, I will be using the example of Austria in order to demonstrate how the stratified educational systems can lead onto a raced and classed higher education access by reducing the opportunities of students with disadvantaged socio-economic and ethnic minority background at the beginning of their educational trajectory.

There are many ethnic minorities living in Austria, comprising about $12.5 \%$ of the Austrian population: there are the so called "historic" minorities officially recognised by the state (e.g. Hungarians, Slovaks, Czechs, Slovenes, Croatians etc), other European migrants, as well as immigrants from Turkey and Yugoslavia often referred to as Gastarbeiter. Turkish guest workers (mostly coming from rural, socially disadvantaged backgrounds) arrived in Austria in the 60s and 70s as a result of shortterm labour migration agreements between Turkey and Austria. Although their migration had been stopped in the 90 s, many have not returned to their home country but settled in Austria for good. As a result of this, Turks today comprise the biggest single ethnic minority in Austria (3\% of the population) ${ }^{1}$. While they are concentrated in certain geographic areas of the country, they are significantly overrepresented in the capital, Vienna, where foreign-born residents make up a third of the population. As a 
consequence of their "negative-selection" " their average educational attainment in Austria remains among the lowest within the OECD countries, while $46 \%$ of Turkishspeaking residents were documented as living in poverty or at risk of doing so still in 2006 (OECD 2009).

Nowadays, the Turkish second generation is coming of age and entering the labour market in increasing numbers. However, existing statistics clearly point to the significant disadvantage the offspring of Turkish guest workers face when they try to navigate the Austrian school system, as only a very small proportion of students reach higher education at all (OECD 2006; Statistik Austria 2011). While statistical data draw attention to second-generation Turks' low participation rate in academic secondary schools as well as the higher education (HE) sector, they fail to offer an insight into the contextualised nature of their educational situation. In order to fill this gap in research, the aim of this paper is to show the variety of pathways these students take to access the Austrian higher education sector. Using the cases of successful students who made it into higher education against the odds of their social, ethnic and school background, the paper seeks to provide an in-depth understanding of the cultural and structural context in which their educational choices are played out.

\section{Ethnic minority children and schooling}

Educational inequalities have been in the forefront of educational and sociological scholarship for many decades. Shavit and Blossfeld's (1993) seminal work documented the stability of socio-economic inequalities in educational opportunities in spite of the dramatic expansion of the educational sector at the end of the $20^{\text {th }}$ century. Their results pointed to the relative advantage associated with privileged origins which contributed to the persistent nature of educational inequalities across many developed societies. These results were in line with the view of capital theorists (see e.g. Bourdieu and Passeron 
[1990]) who suggested that economic, social and cultural resources are equally important for academic success, thus ensuring the social reproduction of those already privileged.

Social class long dominated the discourse on ethnic inequalities in schooling: as ethnic minorities were often disproportionately located at the lower end of the social strata, many scholars believed that social class, and not ethnicity, is the root problem of ethnic inequalities. Ogbu (2003), however, looked into the role of culture when considering ethnic inequalities in schooling. According to him, the label of "acting white" is what keeps many students from doing well in school. He theorised the black and white educational gap in terms of academic disengagement which is rooted in the "oppositional culture" black youth develops in response to their marginalisation. Others approached the issue from the point of view of schools, considering the role teacher stereotyping, labelling and low expectations (Nash 1976) together with institutional racism, play on students' performance and attitudes to schooling.

Exploring the influence of background characteristics on student choices, Ball and his colleagues (Ball, Reay, and David 2002; Reay et al. 2005) constructed two broadly conceived ideal types of ethnic minority chooser (so called "contingent" and "embedded" choosers). By providing an essentially class-based distinction, they argue that ' $[\mathrm{e}]$ thnicity on its own does not explain or account for the choices of minority ethnic students', (Ball, Reay, and David 2002, 335) but it factors into the student decisions. Their first type they refer to is the "contingent"choosers.

Ethnic minority students belonging to this type are typical first-generation applicants with no family tradition of higher education, having parents educated in the country of origin instead of the country of destination. For them, finance, location and ethnic mix are the key concerns in an otherwise distant and "unreal" choice which is characterised by lack of social capital and support. As they have to gather all the 
necessary information singlehandedly, their choice is often vague, reliant on "cold knowledge", namely prospectuses and the web, complemented with some "hot knowledge" (Ball and Vincent 1998), based on first or second hand recommendations of significant others (such as school mates, neighbours). Subjects are more often discussed than courses, while differences in course structures, content or teaching strategy, are seldom taken into account. These ethnic minority choosers often know very little about the institutions they are choosing, and have unrealistic expectations weakly linked to imagined futures, i.e. their choices are not part of a clear long term strategy (Reay et al. 2005). The decision about attending university and obtaining a degree has a 'specific class "meaning" [to the contingent choosers], in addition to, and interwoven with its implications for ethnic identity', which manifests itself in their intentions of choosing a (local) university with an ethnically mixed student body (Ball, Reay, and David 2002, 352).

Conversely, the “embedded” chooser's career aspirations are 'often long standing and vividly imagined, part of a coherent and connected personal narrative' (Reay et al. 2005, 119). This is partly the consequence of having parents who graduated themselves, as a result of which university education becomes part of the "normal biography'. Embedded choosers see university as the entry into high prestige occupations linked to particular career trajectories. Choice is based on extensive research, where a wide range of sources are used including both hot and cold knowledge (Ball and Vincent, 1998). Parents are active participants in the choice, able to mobilize their social capital and to provide both emotional and tangible support. For this type of chooser, finance is no longer an issue and ethnic mix is irrelevant to the choice. While the type and status of university is significant, the university location is secondary in their choices as moving away from home is part of the experience of higher education studies. These two types make a stark contrast: while the embedded choosers are often 
seen as driven by intrinsic benefits, contingent choosers are considered to be driven by extrinsic values.

Overall, Ball's typology is useful in differentiating between certain types of choosers acting on different social conditions, but since very few students fall neatly into one or the other category, its binary character is a clear limitation, while its focus on class does not capture the complexity of student choices. As the status-attainment models (Hossler, Schmit and Vesper 1999) already showed, background characteristics tend to interact with the academic and social environment of schools thus significantly shaping students' higher education decisions. Above and beyond this interaction, there are opportunities and restrictions particular school tracks pose on their students in terms of limiting or allowing access to higher education studies early on. Thus the aim of this paper is to see how such a typology could be adapted to take into account the higher education choices of students in countries with highly stratified educational systems, such as Austria (Allmendiger 1989).

\section{The Austrian educational system}

The Austrian education system is aimed towards preparing young people for specific segments of the labour market. It is a highly stratified system with differences between and within levels. Compulsory education in Austria is one of the shortest among OECD countries, lasting nine school years after the child's sixth birthday. Already after the fourth year of primary school, at the age of 10, pupils are tracked into different types of secondary schools (figure 1). There are two main tracks ${ }^{3}$ at that point: the academic and the general secondary school track. A "very good" or "good" grade in German, Reading and Mathematics is a prerequisite for acceptance to the academic secondary school (AHS). The AHS track is eight years long, generally divided into lower and 
upper secondary education with different streams within ${ }^{5}$ leading onto the Matura, the Austrian school leaving exam ${ }^{6}$.

[figure 1 about here]

The other parallel, but less selective, lower secondary school track is the general secondary school (Hauptschule) ${ }^{7}$ after which not all students continue their studies. Many actually exit the school system in order to take up work or continue in a polytechnic for a year to fulfil the required years of compulsory schooling. The latter is a pre-vocational year which can precede an apprenticeship, which in turn lasts for 3 to 4 years, and includes part-time attendance at a vocational school (Berufschule), generally one day per week. For those keen to study further after the Hauptschule, there are a variety of schools with different durations which combine general education with vocational qualification, e.g. BHS (five years, with Matura) or BMS (from one up to four years, no Matura).

Austria has a binary system of higher education consisting not only of public universities but also universities of applied sciences (Fachhochschulen). Although the vocationally oriented Fachhochschulen were introduced in 1994, over $80 \%$ of all HE students are still enrolled in one of the 22 public universities. Austrian higher education institutions are currently facing the transition from the "old system" of four-five year long Diplomstudium (degree: Magister) to the "new" Bologna-compliant standardised system splitting the long degree programmes into Bachelor and Masters, while at the moment both short and long courses exist side by side (BM BWK 2007).

As the selection has already taken place early on, there is no need for further testing regarding access to HE. At the point of HE access, all students with the necessary secondary school leaving certificate (Matura) - or higher education entrance 
examination $^{8}$ - are able to enrol into higher education courses of their choice as higher education institutions are not able to select students for admission. In practice, however, only about half of those with Matura begin a HE course after completing their secondary schooling. This is in spite of the fact that there are no tuition fees to be paid; higher education is free for all (Austrian and EU) citizens ${ }^{9}$ who complete their studies in the period of the minimum study duration plus two semesters. Only those who take longer to graduate are expected to pay tuition fees for the remainder of their course. Completion, however, is a serious problem in the Austrian HE system, as only about 44\% of students finish at least one HE study within 10 years (Statistik Austria 2011).

\section{Immigrant children in the Austrian educational system}

An interesting feature of the Austrian education system are the so called Special Schools (Sonderschule) catering for children with special needs as well as those pupils who are unable to follow instruction in regular schools. However, it has been documented that immigrant children, and especially the children of Turkish immigrants, are significantly overrepresented in such institutions (Herzog-Punzenberger 2003; Statistik Austria 2011).

Part of the problems of Turkish-speaking children relate to the lack of knowledge of the German language. Many children whose first language is not German are not likely to be proficient in the language of instruction when they enter school at the age of six. The lack of preschool education contributes to this disadvantage as kindergartens are not compulsory and they are open for half a day. As a result, only a small number of children attend preschool ${ }^{10}$ (about $9 \%$ of first graders) (Statistik Austria 2011). The lack of interaction with German-speaking pupils as well as the lack of exposure to German language in preschool years often leads to problems at school once the child is enrolled. Poor language skills cannot be remedied easily since the half- 
day long primary school does not offer sufficient opportunity for language acquisition for pupils for whom German is not their mother tongue.

These initial difficulties subsequently translate into differences in terms of scholastic achievement. International tests showed immigrant students perform below average in key school subjects, such as mathematics, reading and science, the subjects most important for their educational career (OECD 2004, 2006; Pásztor 2008). The results indicated that Turkish pupils often have to repeat one or two school years during compulsory schooling and almost a quarter $(23 \%)$ do not understand German texts (not even at the basic level) at the age of 15 (Pásztor 2008).

Second generation Turks are prone to succeed to their parent's low socioeconomic status as most Turkish parents only attended a few years in school. However, the low socio-economic position of the household is not compensated through schooling. For many pupils the first four primary school years are about learning the language, thus they are unable to get the necessary good marks for accessing the academic track four years after starting school. Hence, their disadvantaged start is determinative for the rest of their schooling as only a quarter of Turkish-speaking pupils end up in tracks leading onto the Matura while over half attend inferior tracks, such as polytechnic, which is a pre-vocational school.

Above all, proficiency in German is the issue; many pupils attend the Hauptschule simply because their German grades are too low to apply to the AHS (or Gymnasium). While $85 \%$ of Turkish-speaking pupils attend general compulsory school (compared to $66 \%$ of German-speaking pupils), a third of those leaving the Hauptschule do not participate in any further education, not even vocational training. This happens in spite of the fact that it is more difficult for ethnic minority background youth to enter the regular labour market; they have longer periods of job-seeking prior to their first proper job and are more likely to be unemployed. As only about $6.5 \%$ of Hautpschule 
pupils follow their education in the university preparatory track, the Gymnasium, early tracking has clear consequences for students' access to HE (Statistik Austria 2011).

The combination of a late school start with early tracking together with the lack of knowledge of the German language are the contributing factors resulting in the low proportion of Turkish-speaking children gaining Matura and being able to access higher education courses in Austria. There is a small proportion of students, however, who in spite of their often disadvantaged immigrant background made it into higher education in Austria. As current scholarship failed to investigate the routes these students took in order to reach $\mathrm{HE}$, in the following, I have analysed the divergent pathways leading onto successful HE careers of second generation Turks, bearing in mind the differences in prior educational trajectories, gender, age, field of study and any variety in their socio-economic and geographic characteristics.

In doing so, I specifically focussed on the offspring of Turkish guest workers, i.e. the second generation, who were born in Austria and obtained their schooling there. Young people of Turkish origin who were enrolled into higher education institutions or were recent graduates were sought out through informal networks, unsolicited communication and snowballing. Ten young people of Turkish origin were interviewed about their educational trajectories, representing the differing pathways to higher education in terms of tracking, parental background and gender. As for the sample, there was an even gender distribution among the participants, the majority of which were between 25 and 29 years old (the rest younger), they were studying a wide range of subjects (ranging from medicine through humanities up to engineering) at higher education level (seven at university). As for parental background, half of the participants' fathers had less than five years of schooling, four between eight and 10 years and only one had a university degree. 
The interview questions, aimed at identifying the educational trajectories of young people, also intended to describe their family background as well as their aspirations, attitudes and experiences of higher education. The interviews generally lasted around two hours, and were carried out in German language and subsequently transcribed and analysed in Atlas.ti. The paper is based on these interviews as well as personal observations of the researcher during visits and some background interviews with secondary school teachers and university lecturers of Turkish origin as well as local data sources.

With regards to data analysis, this paper relies on in-depth analysis of these individual interviews, some of which are used as case studies later on. The student interviews eliciting the educational career paths of young Turks living in Austria produced a narrative account of their higher education choices and career aspirations. A small number of cases, best suited to illustrate the complexity of higher education choices in terms of intersections of ethnicity, social class, gender and prior school track, were selected in order to explain and illustrate the differences between the contrasting experiences of Turkish youth navigating the Austrian school system.

\section{Divergent pathways to higher education: effects of class, ethnicity and tracking}

It is believed that the main driving force behind migration is the aspiration to offer better life for one's offspring, to provide them with educational and labour market opportunities the immigrants themselves were unable to access in their home countries (Zhou and Bankston 1998; Heath et al. 2008; Pásztor 2010). In today’s world, the attainment of a university degree is often a prerequisite to many high-earning and highstatus jobs leading onto a "better life", immigrant parents imagine. While for some of the young people higher education is part of the family tradition and is essential in 
ensuring the social reproduction of advantages, for many others it is the only means for upward social mobility. However, the situation becomes more complicated when ethnic, social, and regional factors come into play making $\mathrm{HE}$ a lot more difficult to reach. Early selection in the stratified educational system can easily put some "behind the starting line”, having their access to HE hindered or even denied, while others are almost "pushed" ahead.

In line with Ball's embedded chooser the case of Yildiz (25, female) illustrates an ethnic minority chooser who has grown up in a family of university-educated parents in the capital city representing all its advantages in terms of access to resources. Her parents (father a building engineer, mother a translator at the court of law), were keen to provide a supportive home and school environment where education was seen as a key to the freedom of soul and strongly encouraged. While Yildiz was bilingual at an early age, able to converse in both Turkish and German, her parents enrolled her in a French speaking school even though they did not speak the language themselves. The international school (dominated by the offspring of diplomats and expatriates of 55 countries) enabled her to navigate in three different cultures and five languages, as she also learned to speak English and Arabic during her studies. Going to university was something her parents always expected her to be doing thus she was well aware of the importance of making a well informed choice. She thought of her options years ahead of her peers and carefully narrowed them down to two potential courses: 'Genetics interested me very much at a time, but essentially I am not a person who would want to spend all her days in a lab, I need social contact, and I like to translate my ideas into reality, to create something to leave behind me.' Although she eventually opted to study architecture at the Technical University in Vienna it was not because she had reduced her pool of universities to those in the locality: 'I think when one goes on to HE, one has got to go to the best university, to find the very best in the field and go there to 
study. If I would have decided to study genetics I would have needed to study in France, as they offer the best education in this field, although I considered Germany and England, too. But because I decided for architecture there wasn't such a need to go abroad.' After a thorough search involving a comparison of institutions and their courses in terms of content, quality and focus, she ruled out the University of Applied Arts and opted for the Technical University because of its focus on sciences. Nevertheless, she felt that some management skills could also come in useful, and so in parallel she enrolled to study management at the Economic University: 'I wanted to combine the two, architecture and business, as I may need the management skills whether I will work for a large company or my own office.' Still, getting her BA in management and a MA in architecture will take some time, as both studies are challenging even when studied individually. Nevertheless, it all seems worth the effort and the time, bearing in mind the career in harbour construction she is aiming to achieve eventually.

The (female) contingent chooser is represented here by the case of Azime (27), who was born and raised in a small town by primary school educated parents working in the textile industry. She attended the local primary school with a majority of Turkish and Yugoslav children. Being the best in her class, she was recommended for Gymnasium and she pushed her parents into agreeing to her choice as she wanted to be at the same school with her best friend from primary school. Although her parents would have preferred a vocational school, Azime got her way and entered the academic stream. Even though she referred to history as her favourite subject from this time, when arriving to the point of higher education choice, she hesitated between architecture and psychology, and eventually settled on the latter as her future course of study. When one of her teachers warned her about the highly scientific content of such a course she became confused and, not knowing what (else) to do, she failed to apply to university at 
all. She could be described as someone working "on the surface of choice" as a result of her unfamiliarity with particular aspects of her chosen field (Reay et al. 2005). As a result, her next years were filled with trial and error, including an expensive study at a media academy, a short stay in the UK and a mundane office job, but she was back on track considering university again following her friends' example who seemed to be doing a "lot more interesting things". Not wanting to make the same mistakes all over again, this time she did her homework properly: she studied the guide book from cover to cover, weighed the pros and cons of every single course, striking out the incompatible course choices. After thoroughly discussing her short list with her closest friends, she stayed with the idea of studying history, with the intention of specialising in cultural studies. Her parents were only observers in this choice as they could not keep up with her ever-changing "career" (e.g. why did she do the expensive course at the academy when she ends up going to university?) and did not quite manage to grasp her choice of history which they considered a second rate subject compared to law or medicine. Now, after five years, she is about to graduate from university but she is unsure whether to start looking for a job or to enrol into postgraduate study.

\section{Contrasting Yildiz and Azime's choices}

The students' ethnicity, as well as their social class, seems to intersect with their early school experiences thus channelling them into differing educational trajectories (table 1). On the surface, Yildiz and Azime seem to have a lot in common: both are successful young women who are enrolled into academic schools allowing them direct access to the universities of their choice. Still the two girls reached secondary education with a different "starting package": while Yildiz' university-educated parents put a high emphasis on education, and considered university as part of a "normal biography"( $\mathrm{Du}$ Bois-Reymond 1998), Azime's parents' dreams did not include a graduation ceremony. 
Here, the international school attended by privileged students gives Yildiz an extra advantage in terms of access to support and resources but also shelters her from the potential effects of racism she could have faced if attending a "regular" school in the inner city. Thus while Yildiz takes a direct route to the prestigious baccalaureate, in spite of being an able student, Azime has to fight for her parents' permission to get into gymnasium at all. In Azime's case, university education is simply "not part of what people like us do", hence her subsequent educational choices are characterised by 'uncertainty, unfamiliarity, lack of knowledge and [...] confusion in relation to the field [of study]' (Reay et al. 2005, 67).

While the academically-oriented secondary schools both girls attend may have ironed out (some of) their original differences, the differences in the resources and support available at their schools clearly manifested in the two women's higher education choices. Ball (et al. 2002, 58) refers to a certain "institutional habitus" when suggesting that 'perceptions and expectations of choice are constructed over time in relation to school friends and teachers "views and advice", that is, "schools develop processes that reflect their SES mix'. Although both girls contemplated going on to university and both considered very similar courses, they had different levels of support and used different means to arrive at their final choice. After thorough consideration of advantages and disadvantages of studying genetics and architecture Yildiz was confident in choosing the latter as a result of a well-informed choice. It is not a surprise that she enrolled directly into her course at university while Azime suffered the consequences of a poorly informed choice once psychology turned out to be an unsuitable alternative. If the two girls had been the same age, Yildiz would already have graduated when Azime reconsidered university studies, having lost three years as a result of her indecisiveness - and lack of support - in planning out her educational trajectory. 
While Azime eventually learns from her experience, and seems to be "catching up" with Yildiz, the two girls are not identically positioned upon completion of university. Yildiz is ahead of Azime by having an 'imagined future' and by having adjusted all her life around it. As Reay (et al. 2005,119) suggests, the career aspirations of embedded choosers are 'often long standing and vividly imagined, part of a coherent and connected personal narrative'. Corresponding to this, Yildiz plans her future in great detail as she begins career-building upon starting her studies. Keeping in mind her ultimate dream of establishing her own architecture practice, she not only studies management to complement her skills, but also takes up a part-time job as an architect's assistant to gain experience in her chosen field. Although her graduation will be delayed due to the various activities she is engaged in, it is important to see that all she does is linked to her ultimate career. Conversely, there is no imagined future for Azime, who, in spite of being much closer to graduation, had not thought of her future options and does not know what she would do with her degree in history. Neither had she sought or obtained relevant work experience like Yildiz, having worked in odd jobs in supermarkets during her HE studies.

Although parental background shapes these young women's educational aspirations and choices, the role parents play is not necessarily reduced to the 'starting package'. Looking at the two girls again, Yildiz enjoyed the full support of her parents who encouraged and supported her unconditionally, even staying up late with her, so that she did not feel "abandoned" studying late at night while everyone slept. Their support was constant, embracing Yildiz in everyday aspects of life. Empowering her with their wisdom, experience and love Yildiz became confident in following her dreams.

On the other hand, Azime's school career is full of parental negotiations: not wanting to see their daughter in gymnasium is just one of the many instances when 
Azime has to convince her parents about a choice of an educational trajectory.

Corresponding to their social background and schooling, the support and encouragement these two girls received was by no means equal and their $a$ priori differences clearly played out in their subsequent educational choices and experiences, shaping their whole educational careers from start to finish.

[table 1 about here]

\section{Extending the model of higher education choice}

As a (male) example of a potential contingent chooser, Ahmet's (29) experiences are in many ways similar to that of Azime. Born as a son of a primary-school-educated father (working in construction) and an illiterate mother (housewife) he suffered from a culmination of cultural, ethnic and economic disadvantage. Unlike other children, he received no presents for Christmas, and was ashamed of not having his own toys when his peers were showing off with mountain bikes or Nike shoes. He felt isolated among his peers while being discriminated against by his teachers, who seemingly exercised stereotyping and low expectations (Nash 1976) when reminding him that getting a "satisfactory" grade should be "good enough for an immigrant kid". Thus his early school years were marked by the experience of racism together with the challenges of having to study in a foreign language. As he had neither friends nor toys, he focused on his homework: 'I had nothing, the only thing I had was my ability to learn, that I could study, and bring good grades home.' After Hauptschule he worked himself up to the BHS, the middle option among the selective secondary schools available to pupils. Here, he received a vocationally-oriented education, completed by a Matura, and did not think of further studies. Only after one of his teachers suggested that he goes onto university did he apply to a Fachhochschule in the capital city to study construction 
engineering. His pool of potential courses was limited to the (only) one he knew: his father worked in construction, all his (male) relatives and cousins were employed in the sector, so not knowing anything else he went for the same field. Not finding his place in the big city led him to drop out after three months of study when he moved back to the town where his parents lived. Thinking through his future with greater maturity he decided to enrol into a local university in order to study mathematics, which he managed to complete successfully.

I love mathematics, really. Sometimes I even dream about it. [But] the first semester was hell for me. It was extreme, I even thought of leaving because I was afraid I won't be able to do it. But after one semester I got the hang of it and it was going well from there.

After graduation he even began postgraduate studies but he was unable to finish it. Having a demanding job and family responsibilities he could not find enough time to spend on his studies: 'when I turn 40 and the kids will be little older and we have repaid the mortgage on our house, perhaps I go back to study and do a $\mathrm{PhD}$, that is my dream.'

The trajectory of indirect access is represented by Erkan $(28$, male) who is the fourth child of primary school educated parents raising seven children in a small village. His home environment is far from stimulating, his widowed father works long hours in the local quarry (his mother died before he turned 15).

When you grow up in a village [like this] you don't keep your hopes high. You aim for learning a vocation, car mechanic, electrician or carpenter, anything really, just that you don't end up in the quarry, that is the other option, the other end, so I rather studied.

Erkan clearly positions people like himself "outside of higher education" (Ball, Reay, and David 2002) where individual choices are the product of surrounding opportunities (Roberts 1993). The bleak prospects lead Erkan from the local primary school, where he regularly faced racism, to the Hauptschule, the non-academic track, 
leading onto an apprenticeship in carpentry. After years of physical labour his future looked bleak until he was injured and his sister-in-law suggested it was time he turned his life around and went back to school to study. He was keen to go back to school immediately but as he exited the educational system without the right qualifications (Matura or Berufsreifeprufung) he could not access any post-secondary course directly. Aiming for a course in media design (following a friend's example) he eventually passed the entrance exam and enrolled in an academy, only to discover that he was unable to secure a job in the field. Once he was "on track" he did not let his hopes for a better life slip and instead redoubled his ambition by settling on to study medicine. The decision is not his alone as he had his family to consider, but his ambitions were threatened by his wife and brothers' vehement opposition to his "irrational" dreams. I had to persuade them, that there is another way that one doesn't have to live the same life as one's parents... So I have gone the opposite way but it took a long time, years, until my family finally agreed to my studies.

Although he finally reached his dream and enrolled in university, the lack of prior foundations made the task almost overwhelming. He found the first year extremely difficult, having exams in chemistry, physics, mathematics and biology, but he also suffered from the chaotic distribution of classes across the capital city where he could not orientate himself easily. Although he did not start off very well, failing all his exams except one in biology, this one successful exam became his motivation for 'staying on' and continuing. As medicine eventually turned out to be too ambitious a choice, he decided to switch to biology:

I was thinking of leaving university, but this single exam which I managed successfully gave me so much strength, such motivation to hold onto -if I was able to do it once it cannot be impossible [second time round]. I was fighting and biting but since that semester I have managed many-many important exams. 
Lacking even the "basics", he had to put significant effort into his studies. He learns by repetition as he is unable to follow the lectures due to language difficulties. Sitting before his books late into the night and during weekends helps him move on gradually:

If I could do all over, with my current knowledge, I would do things differently. Would I have started my studies as 'normal' people at 'normal' time, by now I would have finished even the doctorate. Now it is taking me long but I will get there.

Having completed two years now and finished with most of his exams, he is looking forward to getting his BA next year: 'I think what I am doing now gives me inner freedom. It satisfies me extremely that I am allowed to be at university and that I may study.' His enthusiasm is undiminished; he is eager to learn more and is making further plans for his future: after gaining his masters he hopes to move on to cancer research and eventually get a $\mathrm{PhD}$. 'I remember my wife used to say, you and your great plans, and my brothers laughed at me. But today I can tell them, I haven't dreamt, I have acted, and made my dreams come true.'

While Erkan's case has many parallels with that of the contingent chooser, it is also different, as the track he ends up on does not offer access and leaves him unprepared for higher education studies. Illustrating the specificities of such choice, I introduce the type of the "opportune chooser" in order to emphasise the effects of early tracking on access to higher education study.

The "opportune" chooser generally comes from a disadvantaged family background where parents have little education and children are not exposed to role models other than that of working-class life stories. As a result of social, geographic and ethnic isolation higher education never arises as an imagined future; instead pupils are channelled to follow the least selective vocational school trajectories. Higher education 
as an option usually comes up at an opportune moment, after previous careers have not proved to bring satisfactory life experiences. Since direct access to these educational opportunities is already closed to the individual at this point, strong ambitions are required in order to go back to school and pass examinations allowing them to enter any post-secondary courses. Often, families oppose such ambitions and must be convinced about the propriety and feasibility of such choice. Clearly, completing a degree as an adult with family obligations but without the educational prerequisites has a low likelihood of success, and the challenge is even higher when one wants to study a demanding field. Opportune choosers often lack the necessary capital to make an informed choice and are frequently driven to prestigious courses such as law or medicine as they are unaware of any alternatives. Their choice is often mis-informed and under-researched. They tend to know little to nothing about the content of their chosen course as their decision is directed solely by the prestige of the chosen profession. As a result of lacking the necessary study skills or any support network, their chances of graduating are uncertain if not unlikely.

The somewhat erratic choice process is thought to be a common experience of ethnic minority students who are first generation applicants to HE (Reay et al. 2001, 2005). 'First generation choosers without appropriate cultural capital or relevant social capital may easily find themselves in the "wrong" course with all the risks of drop-out' (Reay et al 2005: 353). . Azime, Ahmet and Erkan are in Bourdieu's (1988) term "lucky survivors", exceptions, deemed "improbable" for the educational position they achieved. Their case studies clearly show that the chances of graduating are clearly linked to the selectivity of secondary schooling and the foundations students gain in these, thus early selection does not only limit higher education access but also the chances of graduation for many ethnic minority students who struggle to catch up with their more privileged peers. 


\section{Ethnic minority access to higher education: Is the "sponsored system" able to ensure equal opportunity to all? Discussion}

Austria considers its stratified educational system as meeting the aspirations of its citizens; however, as demonstrated in this paper, early tracking leads to unequal social situations, considerably reducing the mobility chances of young people from disadvantaged backgrounds. In general, countries greatly differ in the manner their school systems facilitate or impede social mobility. In a sponsored system early tracking is used to segregate the "promising" students from the "unpromising" and prepare them for their destined middle and upper class occupations (Turner 1960). The contest system, on the other hand, is pre-occupied with avoiding any sharp social separation between the superior and inferior students and to keep movement as open as possible. In this system elite status is the prize in an open contest governed by rules of fair play and is taken by the individual's own efforts. In Turner's description, the contest system fairly resembles the American model where all students attend comprehensive schools without being tracked, thus the "real" selection takes place at the doors of higher education institutions. Here, Turner illustrates the sponsored system with the example of England where the 11 plus examinations (in the 1960s) determined the individual's access to grammar schools and the existence of a highly selective system of higher education ensured that individuals are prepared for their destined class positions.

Needless to say, a lot has changed since the sixties when Turner developed this typology. The new era aiming for "equal opportunities" signalled a clear move from a selective towards more comprehensive educational systems offering fair access to education to all. This became particularly evident in the case of the UK, which has seen significant changes implemented in the form of replacing the tripartite system with comprehensive schools and abolishing the binary divide in higher education. 
Nonetheless, the characteristics of the Austrian educational system still appear to resemble the system of sponsored mobility where elite status is "given" and cannot be "taken" by any amount of individual effort. Sponsored mobility rejects the pattern of the contest and favours a controlled selection process in the form of tracking. Tracking is generally meant to prepare young people for the different positions they will occupy in the world of work with the goal of making the best use of talents in society. But the earlier students are tracked, the greater the influence of their ethnic, socio-economic and geographic background on their educational outcomes. As a result, early tracking contributes to the reproduction of inequalities instead of ironing out the existing social divisions. The main problems of tracking are the relatively large disparities between the different tracks as well as the potential rigidity of the system, leaving little or no room for change once pupils are tracked. The limited opportunities of track improvement specifically disadvantage immigrant children who often start off from far behind the starting line. For immigrant children language acquisition often takes up their early years of schooling so they are more likely to turn out as 'late bloomers' in terms of academic performance. But once they "catch up" and able to move forward, their opportunities are significantly restricted both in terms of access and preparation for further study.

Early selection in the Austrian context implies that pupils are distributed into different tracks across the school system at the age of 10 and once again when they are 14. The tracks they are allocated into generally shape their whole educational career but specifically determine their access to HE and the likelihood of getting a degree. While selection seemingly allocates children based on grades reflecting individual abilities, we see how the educational system applies equal rules to unequal pupils. Grades are the culmination of many factors which may mask the prediction of cognitive abilities: the disadvantaged socio-economic situation at home together with language difficulties and 
(in some cases) discrimination faced at school. Many (international) tests have confirmed that the scholastic achievement of children of migration background after only four years of schooling may well more reflect their social background than their aptitude. External events may also be reflected in grades, such as family problems, or as in the case of Erkan, losing a mother at an early age may easily cause academic results to suffer. The weakness of the school system closes many doors for side-tracked students who would want to return to the 'mainstream', disallowing the possibility that students can improve on their previous attainments later on.

The tracks these students are allocated into both reflect and construct inequalities. As middle-class students tend to attend academic secondary schools in good neighbourhoods, working-class ethnic minority students are likely to be enrolled into less equipped, vocationally-oriented, schools. In turn, the classed, raced and gendered assumptions about students' ability and potential will determine the end result of their education: whether their pathways will be lead onto or away from higher education (Archer et al. 2003).

For middle-class students in the academic track, higher education studies are part of normal biography. This is what we see by the case of Yildiz, who never considered not going to university. For those from the lower social classes, HE might seem an unnecessary luxury and unless studying in a university preparatory track (e.g. Azime), they will not be expected to go on with their studies. For those in the BHS, higher education is a possibility, although teachers may not encourage every student to continue with their studies. Here, HE realistically may come up once a child proves himself as academically able at the Matura around the final year of secondary schooling. Needless to say, no one even mentioned university during Erkan's apprenticeship who left school with lower level and fewer qualifications than his more fortunate peers. 
In a sponsored system, (Turner 1960) selection is relatively complete before entrance to university, therefore students are not subject to further testing when applying for HE study. As early selection already assured that those destined for high status jobs are sorted into the right tracks there is no need for re-allocation afterwards. Some of those who were not selected into the academic track may gain access to HE nevertheless, but their preparation will not be as solid as their peers from the university preparatory track, thus the chances of them completing their studies are less assured. Still, those unlucky enough to be sorted into the least selective tracks are not educated with $\mathrm{HE}$ in mind. Even if they consider university they lack the means of access and any foundations necessary for completing such study and gaining a degree afterwards. Although a few manage to escape their fate and succeed in graduating, for the vast majority, the working of the educational system ensures that only those selected early shall receive the right qualifications corresponding to their respective ethnic and class origins, thus reinforcing the inferiority of all other students coming from the least selective tracks. Therefore, seemingly "open and free" higher education is successful in masking the inequalities caused by earlier selections, leading onto questions of equal opportunities and fairness in allocating places in higher education in the Austrian setting. 


\section{References}

Allmendinger, J. 1989. "Educational systems and labour market outcomes.” European Sociological Review 5 (3): 231-50.

Archer, L., M. Hutchings and A. Ross. 2003. Higher education and social class: Issues of exclusion and inclusion. London: RoutledgeFalmer.

Ball, S. and C. Vincent. 1998. "I Heard It on the Grapevine: 'Hot' Knowledge and School Choice.” British Journal of Sociology of Education 19 (3): 377-400.

Ball, S., J. Davis, M. David and D. Reay. 2002. "Classification and judgement: Social class and the cognitive structures of choice of higher education. British journal of sociology of education 23(1): 51-72.

Ball, S., D. Reay and M. David. 2002. "Ethnic Choosing: minority ethnic students, social class and higher education choice". Race Ethnicity and Education 5 (4): 333 - 57. BM BWK. 2007. Bildungswege in Osterreich. [Educational pathways in Austria] Wien: Bundesministerium fur Bildung, Wissenschaft und Kultur.

Bourdieu, P. 1988. Homo Academicus. Cambridge: Polity Press.

Bourdieu, P., and J.C. Passeron. 1990. Reproduction in Education, Society, and Culture. London: Sage.

Du Bois-Reymond, M. 1998. “I don't want to commit myself yet: Young people's life concepts". Journal of Youth Studies no. 1: 63-79.

Heath, A. F., C. Rothon and E. Kilpi. 2008. "The second generation in Western Europe: education, unemployment, and occupational attainment". Annual Review of Sociology (34): 211-35.

Herzog-Punzenberger, B. 2003. "Ethnic segregation in school and labour market - 40 year legacy of Austrian guestworker policy". International Migration Review (37): $1120-44$. 
Hossler, D., J. Schmit and N. Vesper. 1999. Going to college. How social, economic, and educational factors influence the decisions students make. Baltimore: The John Hopkins University Press.

Nash, R. 1976. Teacher expectations and pupil learning. London: Routledge \& Kegan Paul.

OECD. 2004. Learning for tomorrow's world - first results from PISA 2003. OECD.

URL:

http://www.pisa.oecd.org/document/55/0,3343,en_32252351_32236173_33917303_1_1

$\underline{1 \_1,00 . h t m l}$

OECD. 2006. Where immigrant students succeed: A comparative review of performance and engagement in PISA 2003. Paris: OECD. URL:

http://www.oecd.org/document/44/0,3343,en_32252351_32236173_36599916_1_1_1_

$\underline{1,00 . \mathrm{html}}$

OECD. 2008. Education at a Glance 2008: OECD Indicators. Paris: OECD.

OECD. 2009. OECD Reviews of Migrant Education: Austria 2010. Paris: OECD.

URL: http://www.oecd.org/dataoecd/61/6/44192225.pdf

Ogbu, J. U. 2003. Black American students in an affluent suburb. New Jersey: Lawrence Erlbaum Associates.

Pásztor, A. 2008. "The children of guest workers. Comparative analysis of scholastic achievement of Turkish pupils throughout Europe”. Intercultural Education (5): 407419.

Pásztor, A. 2010. “'Go, go on and go higher an’ higher’. Second generation Turks’ understanding of the role of education and their struggle through the Dutch school system“. British Journal of Sociology of Education 31(1): 59-70. 
Reay, D., J. Davies, M. David, and S.J. Ball. 2001. “Choices of Degree or Degrees of Choice? Class, 'Race' and the Higher Education Choice Process”. Sociology 35(4): 855-74.

Reay, D.,M. David and S.J. Ball. 2005. Degrees of Choice. Social class, race and gender in higher education. Stoke on Trent: Trentham Books.

Roberts, K. 2009. Opportunity structures then and now. Journal of Education and Work. 22(5): 355-68.

Shavit, Y. and H-P.Blossfeld. 1993. Persistent Inequality: Changing Educational Attainment in Thirteen Countries. Boulder: Westview Press.

Statistik Austria. 2011. Bildung in Zahlen 2009/10. Schlusselindikatoren und Analysen. [Education in numbers. Key indicators and analyses] Wien: Statistik Austria. URL: http://www.statistik.at/web_de/services/publikationen/5/index.html?id=5\&listid=5\&det ail $=461$

Turner, R. H. 1960. "Sponsored and Contest Mobility and the School System". American Sociological Review 25(6): 855-867.

Zhou, M. and C. L. Bankston. 1998. Growing up American. How Vietnamese children adapt to life in the US. New York: Russel Sage Foundation. 


\section{NOTES}

\footnotetext{
${ }^{1}$ According to Statistik Austria (2010) out of the 8.3 million inhabitants, 112,000 were Turkish citizens and around 250,000 were of Turkish migrant background

${ }^{2}$ In contrast to positive selection (also referred to as "brain drain") negative selection generally refers to the migration of poorer and less educated population of a particular country.

${ }^{3}$ Since the 2008/9 school year a new secondary school model is being tested, the so called New Secondary School, a comprehensive school for all 10-14 year olds.

${ }^{4}$ In Austria, scholastic grades use a 5-point grading scale, 1 ("very good") being the best and 5 ("unsatisfactory") being the worst grade.

5 From the third grade students are allocated into three streams: gymnasium (focus on: Latin and other languages), realgymnasium (focus on: mathematics, physics, biology, chemistry) and wirtschaftskundiges realgymnasium (economics, geography, psychology, philosophy).

${ }^{6}$ The Matura is essential for access to higher education as well as to other types of post-secondary education, such as academies.

${ }^{7}$ Within the Hauptschule students are further allocated into different "achievement groups" (Leistungsgruppen).

${ }^{8}$ Students without a Matura can access HE via entrance exams such as: Berufsreifeprufung or Studienberechtigungsprufung.

${ }^{9}$ Students who are not EU citizens must pay tuition fees of EUR 363.36 per annum.

${ }^{10}$ Kindergarten attendance only became mandatory for all 5 year olds in 2010 (Statistics Austria)
} 